Maciej GIS

\title{
Comparative studies of exhaust emission from diesel engine fuelled with diesel fuel and B100 fuel
}

The article presents a comparative study of carbon monoxide, hydrocarbons, nitrogen oxides and the mass and number of particulate of diesel engine fulled with diesel and B100. B100 is a biofuel produced from vegetable oils for vehicles with compression-ignition engines. B100 fuel and diesel have similar physical-chemical characteristics which have been analyzed.

The research was carried out on an engine dynamometer in four cycles: ESC, ETC, WHSC and WHTC. The article provides an analysis of the research results, preceded by a discussion of the test cycles used.

Key words: diesel fuel, B100 fuel, ecology, engine

\section{Introduction}

With air pollution and increasingly restrictive requirements concerning the emission of harmful combustion substances, it is crucial to search for and use fuels from sources other than crude oil, including renewable sources, oilseeds, e.g. rape seed oil. Given the above, the self-ignition engine is suitable as it demonstrates a relatively low sensitivity to changes of fuel's physical \& chemical properties.

Modern-day SI engines adapted to combust fuels derived from crude oils cannot be powered with natural rape seed oil due to problems relating to the immobilization of pressure elements, carbonisation of sprays, the occurrence of varnish in the combustion chamber and poorer lubricity properties of the engine oil $[1,10]$.

The content of glycerides in natural rape-seed oil accounts on average for $95-98 \%$. Glycerides together with natural substances soluble in fat form a group of compounds known as lipids [2]. Large and heavy particles of rape-seed oil can be decreased by way of transesterification. Noteworthy results of the transesterification of natural rape-seed oil include considerable decrease of particles and significant reduction of viscosity (up to 10 times), the elimination of triglycerides (and thus reducing the varnish in the combustion chamber), as well as decrease of the cloud and solidification point and improved fuel volatility $[1,10]$.

B100 (methyl esters of fatty acids) is a biofuel produced in the country based on vegetable oils, intended for vehicles with SI engines.

The offered biofuel has a beneficial effect on the operation and durability of the engine; owing to good lubricity properties it protects the injection elements against excessive wear [5]. Greater content of oxygen compared to traditional diesel fuel manifests in "better" combustion, while a high cetane number ensures good engine performance. B100 biofuel meets the quality standards set forth bio-diesel according to PN-EN 14214 standard applicable on EU markets [7, 10]. Because of lowtemperature characteristics (CFPP), there are three types of B100 biofuel: B, D and F (corresponding to fuels of temperate climate zones) and class 2 - corresponding to the fuel for arctic or harsh winter climate [12]:

- B100 type B with CFPP no greater than $0^{\circ} \mathrm{C}$,

- B100 type D with CFPP no greater than $-10^{\circ} \mathrm{C}$,

- B100 type F with CFPP no greater than $-20^{\circ} \mathrm{C}$.

The last fuel continued to be available and was subject to evaluation, and its use in comparative studies covering commercial diesel fuel, in tests of IVECO engine allowed for comparing the emission of polluting combustion substances in the use of both fuels.

\section{The purpose and scope of research}

The purpose of the research was to perform comparative tests of emission of polluting combustion gases from a CI engine IVECO N60 ENT C, fuelled with diesel and B100 biofuel, in ESC, ETC, WHSC and WHTC cycles. The starting point for the tests was to define the advantages of using environmentally-friendly B100 biofuel in terms of emission of polluting combustion gases compared to conventional diesel fuel used in the same engine.

\section{The tested objects}

The tests comprised commercial diesel fuel and B100 fuel in N60 ENT C engine by IVECO.

The parameters of the tested fuels are presented in Table 1 (for diesel fuel) and in Table 2 (for B100 fuel).

Table 1. Parameters of diesel fuel [11]

\begin{tabular}{|l|c|c|c|c|}
\hline \multirow{2}{*}{ Parameter } & \multirow{2}{*}{ Unit } & \multicolumn{2}{|c|}{ Range } & \multirow{2}{*}{ Test method } \\
\cline { 3 - 4 } & & min. & max. & \\
\hline Cetane number & - & 51.0 & - & PN-EN ISO 5165 \\
\hline $\begin{array}{l}\text { Density at temp. } \\
15^{\circ} \mathrm{C}\end{array}$ & $\mathrm{kg} / \mathrm{m}^{3}$ & 820.0 & 845.0 & $\begin{array}{c}\text { PN-EN ISO 12185 } \\
\text { PN-EN ISO 3675 }\end{array}$ \\
\hline Sulphur content & $\mathrm{mg} / \mathrm{kg}$ & - & 10.0 & $\begin{array}{c}\text { PN-EN ISO 20846 } \\
\text { PN-EN ISO 20884 }\end{array}$ \\
\hline Ignition temperature & ${ }^{\circ} \mathrm{C}$ & 56.0 & - & PN-EN ISO 2719 \\
\hline $\begin{array}{l}\text { Kinematic viscosity } \\
\text { at 40 }\end{array}$ & $\mathrm{mm}^{2} / \mathrm{C}$ & 2.000 & 4.500 & PN-EN ISO 3104 \\
\hline CFPP temperature & ${ }^{\circ} \mathrm{C}$ & - & -20 & PN-EN 116 \\
\hline
\end{tabular}

The basic technical data of IVECO N60 ENT C engine are presented in Table 3, whereas the view of the engine installed in the testing unit is shown in Fig. 1. 
Table 2. Parameters of B100 fuel [11]

\begin{tabular}{|l|c|c|c|c|}
\hline \multirow{2}{*}{ Parameter } & \multirow{2}{*}{ Unit } & \multicolumn{2}{|c|}{ Range } & \multirow{2}{*}{ Test method } \\
\cline { 3 - 4 } & & min. & max. & \\
\hline Cetane number & - & 51.0 & - & PN-EN 14214 \\
\hline $\begin{array}{l}\text { Density at temp. } \\
15^{\circ} \mathrm{C}\end{array}$ & $\mathrm{kg} / \mathrm{m}^{3}$ & 860.0 & 900.0 & PN-EN 14214 \\
\hline Sulphur content & $\mathrm{mg} / \mathrm{kg}$ & - & 10.0 & PN-EN 14214 \\
\hline Ignition temperature & ${ }^{\circ} \mathrm{C}$ & 101.0 & - & PN-EN 14214 \\
\hline $\begin{array}{l}\text { Kinematic viscosity } \\
\text { at } 40^{\circ} \mathrm{C}\end{array}$ & $\mathrm{mm}^{2} / \mathrm{s}$ & 3.500 & 5.000 & PN-EN 14214 \\
\hline CFPP temperature & ${ }^{\circ} \mathrm{C}$ & - & -20 & PN-EN 14214 \\
\hline $\begin{array}{l}\text { Content of methyl } \\
\text { ester of linoleic acid }\end{array}$ & $\%(\mathrm{~m} / \mathrm{m})$ & - & 12 & PN-EN 14214 \\
\hline $\begin{array}{l}\text { Methyl alcohol } \\
\text { content }\end{array}$ & $\%(\mathrm{~m} / \mathrm{m})$ & - & 0.20 & PN-EN 14214 \\
\hline
\end{tabular}

Table 3. Technical data of the tested engine [11]

\begin{tabular}{|l|l|}
\hline Engine type & N60 ENT C \\
\hline Number of cylinders & 6 \\
\hline Arrangement of cylinder & In-line \\
\hline Engine displacement & $5.9 \mathrm{dm}^{3}$ \\
\hline Nominal power & $194 \mathrm{~kW}$ \\
\hline Max. torque & $1000 \mathrm{Nm}$ at $1400 \mathrm{rpm}$ \\
\hline Fuel injection system & direct, Common Rail \\
\hline Combustion purification system & SCR \\
\hline Type of fuel & Diesel fuel \\
\hline Turbocharger system & TCA \\
\hline Date of production & Maj 2012 \\
\hline Combustion gases standard & Euro V \\
\hline $\begin{array}{l}\text { Certificate of approval regarding } \\
\text { emission of combustion pollutants }\end{array}$ & e3*2005/55*2008/74K*1035*05 \\
\hline Certificate of approval (power) & E3 85R-021218*01 \\
\hline
\end{tabular}

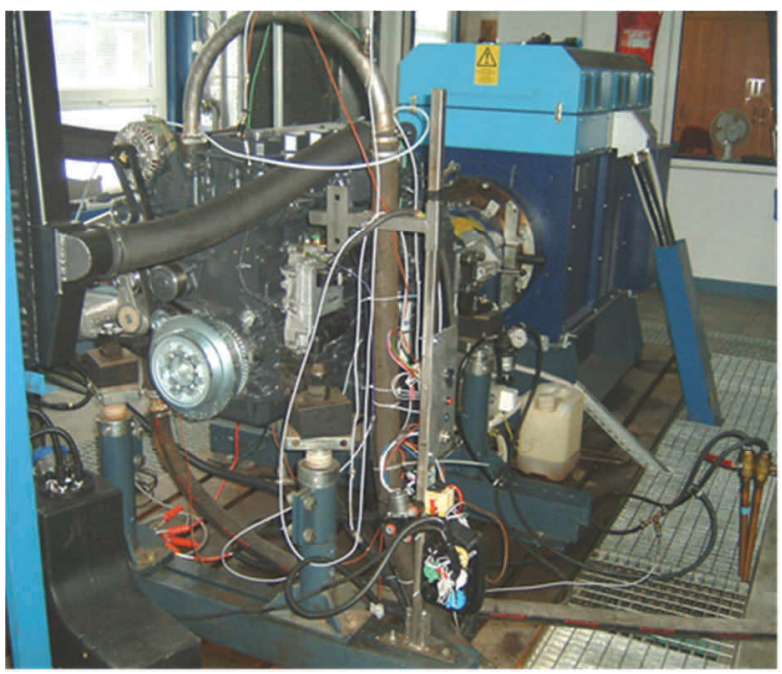

Fig. 1. IVECO N60 ENTC engine installed in the testing unit

\section{Testing unit}

The tests were conducted in the Motor Transport Institute in a testing unit equipped with an engine test bench, consisting of (Fig. 2, Fig. 3):

- an asynchronous electrical machine (capable of operating as an engine-generator) of AVL type AFA 100 4Z4/4 with a current frequency transformer; the unit allows for recreating dynamic tests and can be used for measuring the emission of combustion pollutants in line with the regulations currently in force;

- a digital rotation speed metering device Heidenham ROD 4261024 27S12-03,
- a torque measuring shaft T10F 063230022 HBM installed on the shaft linking the engine with the brakes, which allows to eliminate - in dynamic position of the engine's operation - the impact of breakaway torque of the brake's rotor on temporary torque developed by the engine;

- a flow meter to measure fuel consumption - AVL 735, compatible with AVL 753, ensuring constancy of fuel's temperature during the measurement;

- a set of combustion analysers AMA i60 adapted to analyse undiluted combustions, consisting of a double set of analysers to gauge emission before and behind the combustion purification unit;

- an air flow-meter Sensyflow P to measure air consumption in the engine, effected by measuring the resistance of the heated wire;

- a set of thermometers and manometers to measure temperature and pressure of various media inside the engine (air, oil, coolant and combustion gases).

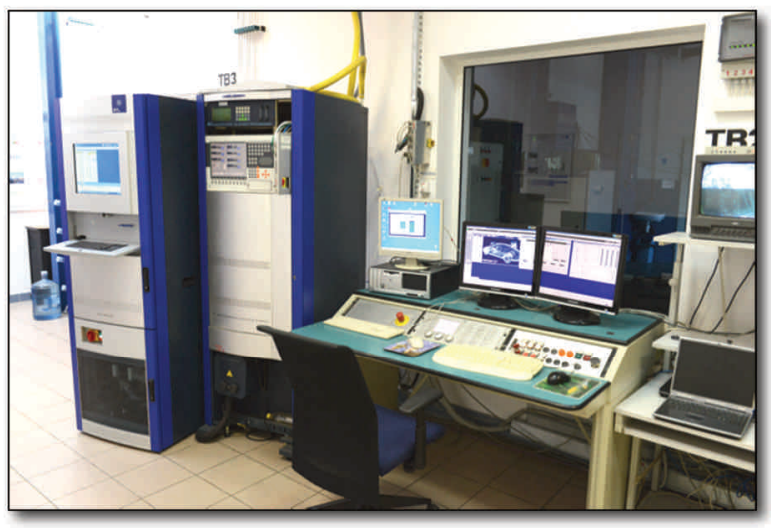

Fig. 2. A set of analysers AMA i60 R2 and CEB II

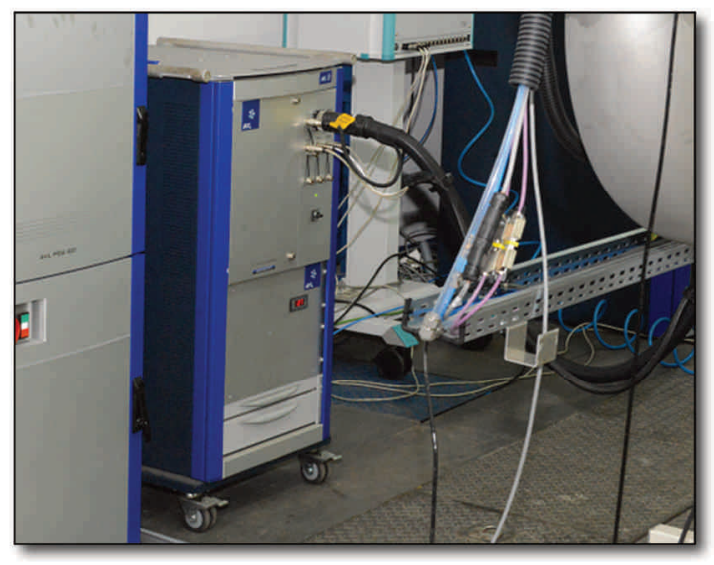

Fig. 3. AVL particulate matter measuring unit

\section{Measuring cycles}

The studies of emission of combustion pollutants generated by IVECO N60 ENTC engine fuelled with diesel and B100 were carried out with the engine test bench. The tests were performed in four cycles: ESC, ETC and WHSC and WHTC (Fig. 4, Fig. 5, Fig. 6, Fig. 7). 


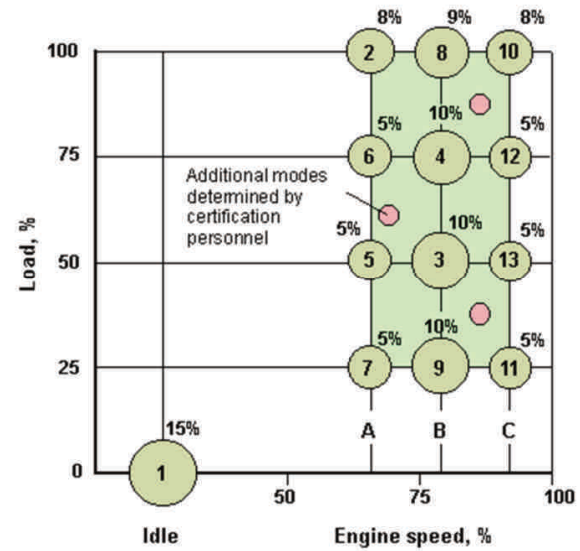

Fig. 4. European ESC cycle [9]

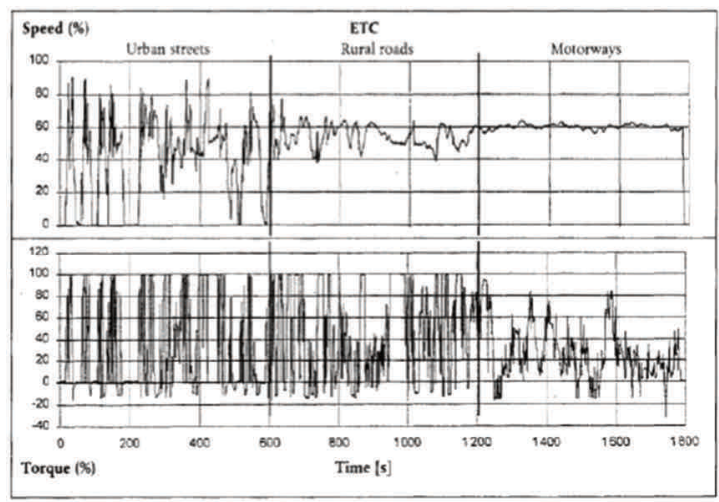

Fig. 5. ETC Transient Cycle - engine speed [9]

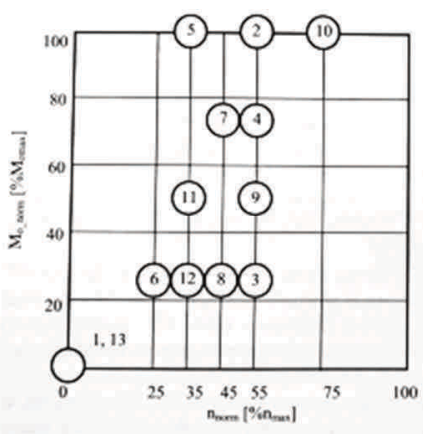

\begin{tabular}{|c|c|c|}
\hline Faza & $\begin{array}{c}u_{i} \\
{[-]}\end{array}$ & $\begin{array}{c}5 \\
{[s]}\end{array}$ \\
\hline 0 & 0,24 & -24 \\
1 & $0,17 / 2$ & 210 \\
2 & 0.02 & 50 \\
3 & 0.10 & 250 \\
4 & 0,03 & 75 \\
5 & 0,02 & 50 \\
6 & 0,08 & 200 \\
7 & 0.03 & 75 \\
8 & 0,06 & 150 \\
9 & 0.05 & 125 \\
10 & 0,02 & 50 \\
11 & 0,08 & 200 \\
12 & 0,10 & 250 \\
13 & $0,17 / 2$ & 210 \\
\hline
\end{tabular}

Fig. 6. Scheme of standardized WHSC cycle and coefficients participation phase [6]

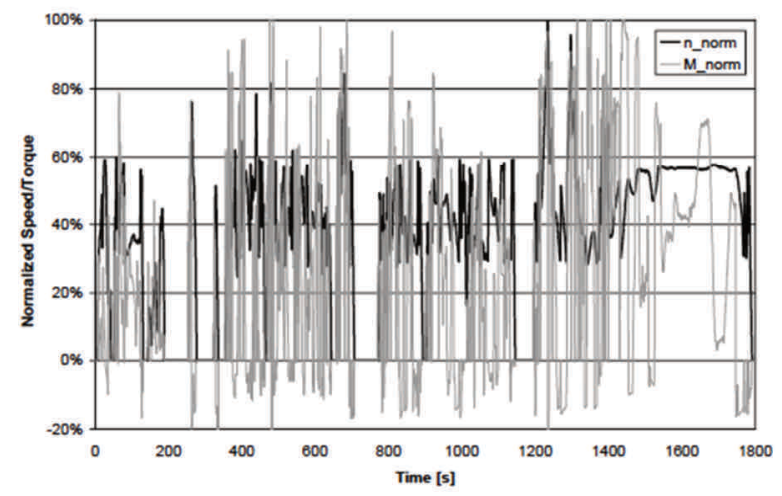

Fig. 7. European WHTC Cycle [8]

\section{Testing process}

The tested engine IVECO N60 ENTC was produced in May 2012 and therefore subject to approval as regards conformity with EURO V standard. It was certified with a certificate of approval no. e $3 * 2005 / 55 * 2008 / 74 \mathrm{~K} * 1035 * 05$ and the tests were performed pursuant to Directive 2005/55/EC [4] amended by Directive 2008/74/EC [3]. The abovementioned directives and the corresponding UN Vehicle Regulations - Rev. 05 did not envisage the method of approval as regards engines with bi-fuel system. The tests of bi-fuel engines were introduced on 06.08.2013 together with Rev. 06 of UN Vehicle Regulations 49. However, Review 06 describing the approval tests for engines with a bi-fuel system applies to engines that fulfil the limit of Euro VI requirements, thus engines tested in completely different cycles than Euro V engines. Euro V engines were tested in ESC and ETC cycles, whereas Euro VI engines are tested in WHSC and WHTC cycles.

Due to the above reasons, this study - which aimed at comparing the emissions of pollutants generated by the engine when fuelled with diesel and B100 compliant with Euro $\mathrm{V}$ regulations, in its basic versions fuelled with diesel - was based on methods described in Directive 2005/55/EC [4] and UN Vehicle Regulations - Rev. 05, making only necessary adjustments in the bi-fuel engine calculations, in accordance with UN Vehicle Regulations - Rev. 06, where required.

The tests were carried out in ESC, ETC in accordance with Directive 2005/55/EC, with the use of two different types of fuel. In the first case the engine was fuelled with diesel only, whereas in the second case with B100.

\section{Analysis of test results}

Table 4 presents results of tests of emission of combustion pollutants in the tested engine fuelled with diesel and B100, in different testing cycles applied in engine approval tests.

Table 4. Emission test results in different cycles $[\mathrm{g} / \mathrm{kWh}]$

\begin{tabular}{|c|c|c|c|c|c|c|c|c|}
\hline \multirow[b]{2}{*}{ Test } & \multicolumn{2}{|c|}{$\mathrm{CO}$} & \multicolumn{2}{|c|}{ NOx } & \multicolumn{2}{|c|}{ THC } & \multicolumn{2}{|c|}{ PN } \\
\hline & Z Z & $\frac{8}{\infty}$ & Z & $\frac{8}{\infty}$ & Z & $\frac{8}{\infty}$ & Ž & $\frac{8}{\infty}$ \\
\hline$\underset{\mathscr{~}}{\tilde{\Psi}}$ & 0.509 & 0.340 & 1.728 & 2.300 & 0.024 & 0.030 & 10.906 & 2.699 \\
\hline$\underset{⿱ ⺌ 兀}{\circlearrowright}$ & 0.694 & 0.541 & 1.811 & 2.345 & 0.022 & 0.028 & 13.973 & 10.308 \\
\hline $\begin{array}{l}U \\
\mathscr{n} \\
3\end{array}$ & 1.317 & 1.040 & 2.710 & 3.250 & 0.023 & 0.029 & 11.876 & 7.018 \\
\hline 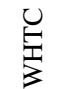 & 1.926 & 1.473 & 5.136 & 5.718 & 0.063 & 0.061 & 9.317 & 18.516 \\
\hline 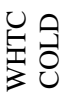 & 3.375 & 1.336 & 8.459 & 5.867 & 0.137 & 0.045 & 43.168 & 8.464 \\
\hline
\end{tabular}


According to Table 4 and Fig. 8 the unit emission of $\mathrm{CO}$ is lower when B100 fuel is used, compared to diesel fuel, in all test cycles.

THC emissions are practically analogous in ESC, ETC, WHSC and WHTC cycles when the engine is fuelled with diesel and B100, except for WHTC Cold, where the emission for diesel fuel is definitely greater (Fig. 9).

The level of particulate matter is clearly lower in ESC, ETC, WHSC and WHTC Cold cycles when fuelled with B100, except for WHTC (Fig. 11).

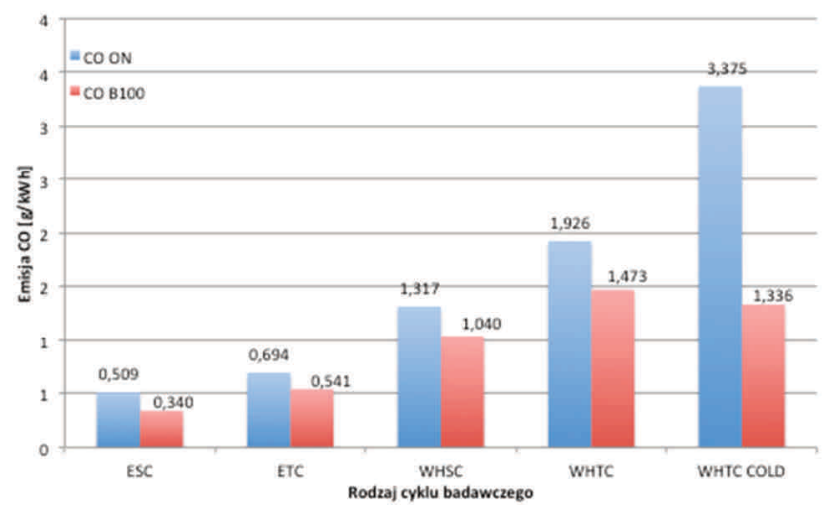

Fig. 8. Comparison of $\mathrm{CO}$ emission in an engine fuelled with diesel and $\mathrm{B} 100$, depending on the type of test

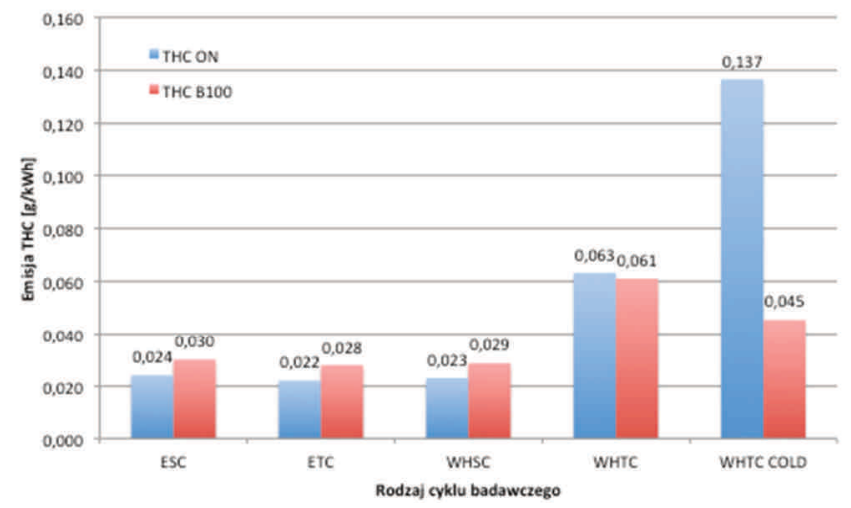

Fig. 9. Comparison of THC emission in an engine fuelled with diesel and B100, depending on the type of test

The unit emission of NOx is clearly greater in ESC, ETC, WHSC and WHTC cycles when fuelled with B100, except for WHTC Cold (Fig. 10).

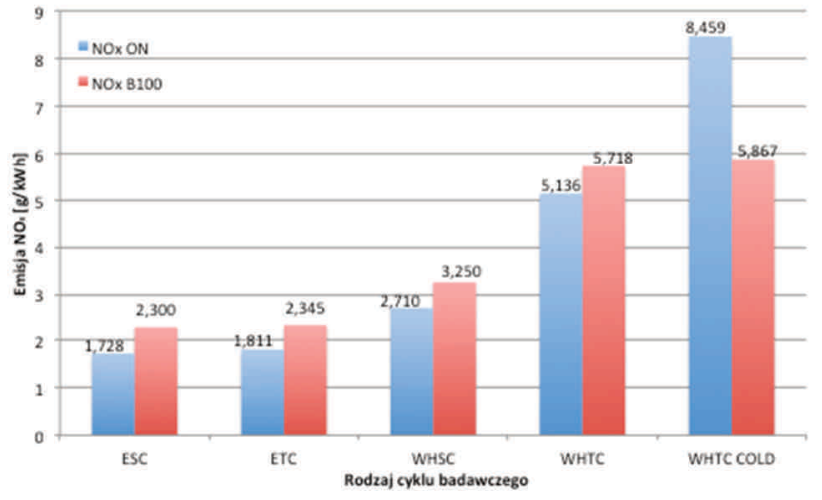

Fig. 10. Comparison of $\mathrm{NO}_{\mathrm{x}}$ emission with engine fuelled by diesel and B100, depending on the type of test

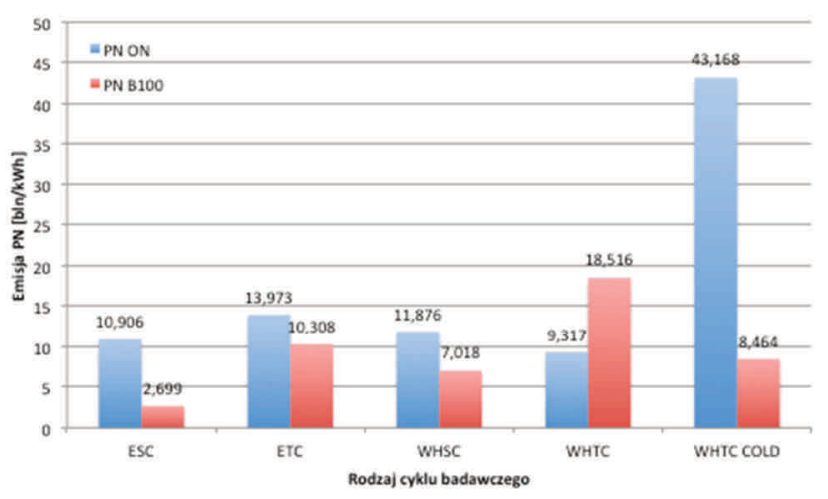

Fig. 11. Comparison of PN emission in an engine fuelled with diesel and $\mathrm{B} 100$, depending on the type of test

\section{Summary}

The tests lead to the following conclusions:

- the use of B100 to fuel a combustion engine in general has a positive impact on PM emission levels;

- the tendency to a lower emission is also noticeable in case of carbon oxide (CO) and to a lesser degree - also in the case of hydrocarbons (THC);

- the use of B100 to fuel a combustion CI engine affects the emission of nitrogen oxides (NOx);

- respective test cycles differ considerably in terms of emission levels with regard to all harmful substances. The lowest emissions have been achieved in ESC cycle and tend to increase in ETC, WHSC, WHTC and WHTC Cold cycles.

\section{Nomenclature}

CFPP cold filter plugging point

$\mathrm{CO}$ carbon monoxide

$\mathrm{CO}_{2} \quad$ carbon doxide

ESC European Stationary Cycle

ETC European Transient Cycle

$\mathrm{NO}_{\mathrm{x}}$ nitrogen dioxide
SI spark ignition

PN particular number

THC total hydrocarbons

WHSC World Harmonized Stationary Cycle

WHTC World Harmonized Transient Cycle 


\section{Bibliography}

[1] BACZEWSKI, K., KAŁDOŃSKI, T. Paliwa do silników o zapłonie samoczynnym. WKE 2004.

[2] CISEK, J., MRUK, A. Właściwości silnika ZS zasilanego naturalnym olejem rzepakowym. Zeszyty Naukowe Instytutu Pojazdów. 2012, 1(87). Warsaw University of Technology.

[3] COMMISSION DIRECTIVE 2008/74/EC of 18 July 2008 amending, as regards the type approval of motor vehicles with respect to emissions from light passenger and commercial vehicles (Euro 5 and Euro 6) and access to vehicle repair and maintenance information, Directive 2005/55/EC of the European Parliament and of the Council and Directive 2005/78/EC (Text with EEA relevance).

[4] DIRECTIVE 2005/55/EC of the European Parliament and of the Council of 28 September 2005 on the approximation of the laws of the Member States relating to the measures to be taken against the emission of gaseous and particulate pollutants from compression-ignition engines for use in vehicles, and the emission of gaseous pollutants from positive-ignition engines fuelled with natural gas or liquefied petroleum gas for use in vehicles (Text with EEA relevance).

[5] KRUCZYŃSKI, W., KOŁODZIEJCZYK, K., OWCZUK, M. et al. Ocena zastosowania estrów metylowych różnego pochodzenia w silnikach o zapłonie samoczynnym. Zeszyty Naukowe Instytutu Pojazdów. 2012, 2(88), Warsaw University of Technology.

[6] MERKISZ, J., PIELECHA, J., RADZIMIRSKI, S. Pragmatyczne podstawy ochrony powietrza atmosferycz- nego w transporcie drogowym. Wydawnictwo Politechniki Poznańskiej. Poznań 2009.

[7] PN-EN 14214. Ciekłe przetwory naftowe - Estry metylowe kwasów tłuszczowych (FAME) do użytku w silnikach samochodowych o zapłonie samoczynnym (Diesla) i zastosowań grzewczych - Wymagania i metody badań.

[8] REGULATION No. 49 Rev. 6. Uniform provisions concerning the measures to be taken against the emission of gaseous and particulate pollutants from compression ignition engines and positive ignition engines for use in vehicles. E/ECE/324/Rev.1/Add.48/Rev.6 - E/ECE/TRANS/ 505/Rev.1/Add.48/Rev.6.

[9] REGULATION No. 49. Rev. 7. Uniform provisions concerning the measures to be taken against the emission of gaseous and particulate pollutants from compressionignition engines for use in vehicles, and the emission of gaseous pollutants from positive-ignition engines fuelled with natural gas or liquefied petroleum gas for use in vehicles. E/ECE/324/Rev.1/Add.48/Rev.7-E/ECE/TRANS/ 505/Rev.1/Add.48/Rev.7

[10] SZLACHTA, Z. Zasilanie silników wysokoprężnych paliwami rzepakowymi. WKŁ 2002.

[11] TEST RAPORT NO 115520/COŚ. Badania emisji zanieczyszczeń silnika Iveco typ N60 ENT C zasilanego olejem napędowym oraz paliwem B100.

[12] www.orlen.pl

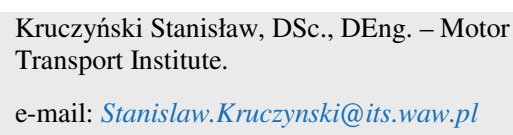

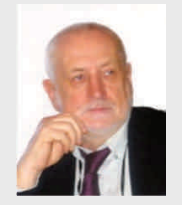
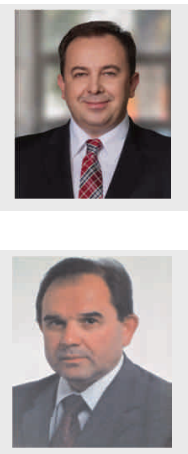
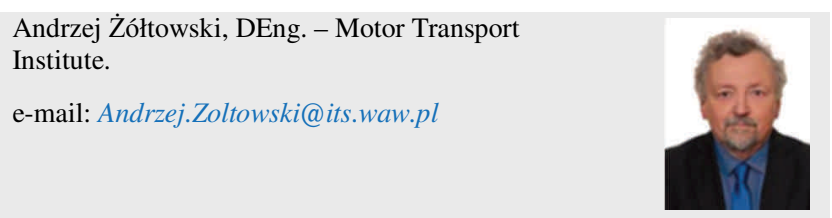

Maciej Gis, MEng. - Protection Environment Center in Motor Transport Institute.

e-mail:Maciej.Gis@its.waw.pl 